Hittite Landscape and Geography 


\title{
Handbook of Oriental Studies
}

SECTION 1

\author{
The Near and Middle East
}

ANCIENT NEAR EAST

Editor-in-Chief

M. Weeden (London)

Editors

C. Leitz (Tübingen)

H. Gzella (Leiden)

C. Waerzeggers (Leiden)

D. Wicke (Mainz)

C. Woods (Chicago)

VOLUME 121 


\title{
Hittite Landscape and Geography
}

\author{
Edited by \\ Mark Weeden and Lee Z. Ullmann
}

With maps by

Zenobia Homan

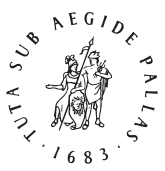

B R I L L

LEIDEN | BOSTON 
Cover illustration: The Approach to Hattusa from the North

Copyright German Archaeological Institute

Library of Congress Cataloging-in-Publication Data

Names: Weeden, Mark, edtior. | Ullmann, Lee Z., editor. | Homan, Zenobia, cartographer.

Title: Hittite landscape and geography / edited by Mark Weeden and Lee Z. Ullmann ; with maps by Zenobia Homan.

Other titles: Handbook of Oriental studies. Section one, Near and Middle East (2014); v. 121.

Description: Leiden ; Boston : Brill, 2017. | Series: Handbook of Oriental studies. Section 1, The Near and Middle East ; volume 121 | Includes bibliographical references.

Identifiers: LCCN 2017023170 | ISBN 9789004341746 (hardback : alk. paper)

Subjects: LCSH: Hittites—Civilization. | Landscape archaeology_Turkey. |

Turkey-Historical geography.

Classification: LCC DS66 .H547 2017 | DDC 939/.3-dc23

LC record available at https://lccn.loc.gov/2017023170

Typeface for the Latin, Greek, and Cyrillic scripts: “Brill”. See and download: brill.com/brill-typeface.

ISSN 0169-9423

IS BN 978-90-04-34174-6 (hardback)

Copyright 2017 by Koninklijke Brill NV, Leiden, The Netherlands.

Koninklijke Brill NV incorporates the imprints Brill, Brill Hes \& De Graaf, Brill Nijhoff, Brill Rodopi and

Hotei Publishing.

All rights reserved. No part of this publication may be reproduced, translated, stored in a retrieval system,

or transmitted in any form or by any means, electronic, mechanical, photocopying, recording or otherwise, without prior written permission from the publisher.

Authorization to photocopy items for internal or personal use is granted by Koninklijke Brill NV provided that the appropriate fees are paid directly to The Copyright Clearance Center, 222 Rosewood Drive,

Suite 910, Danvers, MA 01923, USA. Fees are subject to change.

This book is printed on acid-free paper and produced in a sustainable manner. 
This book is dedicated to the memory of Mustafa Süel and Tony Wilkinson

\section{$\because$}

9789004341746_Weeden_text_proof-02.indb 5 


\title{
Contents
}

\author{
List of Figures IX \\ List of Sigla and Abbreviations XII \\ Textual and Bibliographical Abbreviations XIII \\ 1 Introduction 1 \\ Mark Weeden and Lee Z. Ullmann
}

\section{PART 1}

Perspectives based Primarily on Archaeological Evidence

2 The Land of the Hittites: Airs, Waters and Places 17 Neil Roberts

3 The Discovery of a Hittite City Developments in Hittite Geography based on the Identification of Ortaköy-Šapinuwa 28 Aygül Süel and Mustafa Süel

$4 \quad$ Hattusa and its Environs: Archaeology 37 Andreas Schachner

5 Central East: Archaeology. Alacahöyük, Eskiyapar, Ortaköy, Maşathöyük 50

Mustafa Süel, Aygül Süel, Tunç Sipahi and Mark Weeden

6 The East: Archaeology. The Upper Land, Azzi-Hayaša, Išuwa 58 Andreas Müller-Karpe

7 The North: Archaeology 75
Claudia Glatz

8 South-Central: Archaeology 89

Alvise Matessi and Bianca Maria Tomassini Pieri

9 Central West: Archaeology 106

Kimiyoshi Matsumura and Mark Weeden

10 The West: Archaeology 119

Sevinç Günel

11 Kizzuwatna: Archaeology 134

Mirko Novák and Susanne Rutishauser

12 The Euphrates States and Elbistan: Archaeology 146 Michael Brown and Tony J. Wilkinson

13 The Northern Levant: Archaeology 159 Jesse Casana 
PART 2

\section{Perspectives based Primarily on Philological Evidence}

14 Hattuša and Environs: Philology 179

Özlem Sir Gavaz

15 Central East: Philology 200

Aygül Süel and Mark Weeden

16 The East: Upper Land, Išuwa-Malitiya, Azzi-Hayaša Philology 209 Metin Alparslan

17 The North: Hanhana, Hattena, Ištahara, Hakpiš, Nerik, Zalpuwa, Tummana, Pala and the Hulana River Land 219 Carlo Corti

18 South Central: The Lower Land and Tarhuntašša 239 Massimo Forlanini

19 Central West: Philology 253 Stefano de Martino

20 The West: Philology 262 Max Gander

21 Kizzuwatna and the Euphrates States: Kummaha, Elbistan, Malatya: Philology 281

J. David Hawkins and Mark Weeden

22 The Historical Geography of Hittite Syria: Philology 295 Yoram Cohen

23 A Commercial Geography of Anatolia: Integrating Hittite and Assyrian Texts, Archaeology and Topography 311 Gojko Barjamovic

24 Moving through the Landscape in Hittite Texts 319 Jürgen Lorenz

Bibliography 325

Index 388 